\title{
Investigation of Teaching Competencies to Enhance Students' EFL Learning at Taif University
}

\author{
Tha'er Issa Tawalbeh ${ }^{1} \&$ Nasrah Mahmoud Ismail ${ }^{1}$ \\ ${ }^{1}$ English Language Center, Taif University, Taif, Kingdom of Saudi Arabia \\ Correspondence: Tha'er Issa Tawalbeh, English Language Center, Taif University, Hawiyah, Building No. 7000, \\ P.O Box 888, 21974 Taif, Kingdom of Saudi Arabia. Tel: 966-599-234-100. E-mail: anasthaer@hotmail.com
}

Received: July 23, 2014 Accepted: September 16, 2014 Online Published: October 29, 2014

doi:10.5539/ies.v7n11p84 URL: http://dx.doi.org/10.5539/ies.v7n11p84

\begin{abstract}
The paper aimed to investigate the teaching competencies implemented by instructors to enhance EFL students at Taif University in Saudi Arabia. The first two questions discussed the degree of implementing the teaching competencies, which either enhance or hinder learning. The third and fourth questions were an attempt to examine if there were any significant differences at $(\alpha=0.05)$ due to instructors' qualifications and years of experience. The researcher developed an observation checklist to investigate the degree of implementing the competencies. There were four domains: preparation, instruction, assessment, and educational climate. The findings of the first two questions showed that preparation and educational climate include the competencies where the instructors displayed satisfactory performance. However, instruction and assessment include the competencies which were rarely or not demonstrated. The results of the third question showed that there were significant differences. However, there were no significant differences due to years of experience. The findings of the first two questions could be due whether or not instructors have undergone professional development to equip them with the competencies required to enhance students' learning. The results of the third question could be due to the fact that instructors having a diploma after the bachelor degree helped them make difference. The result of the fourth question could be due to the educational context that didn't support instructors' years of experience.
\end{abstract}

Keywords: English as a foreign language (EFL), preparatory year program, Taif University teaching competencies, teaching practices

\section{Introduction}

Instructors of English implement a variety of teaching practices that reflect the teaching competencies they have acquired during their teaching career. These practices might range from direct instruction using lectures, cooperative learning strategies, task-based learning, critical thinking and problem solving techniques, and paper and pencil tasks. These practices are used to achieve certain objectives in the classroom. However, instructors' failure to have a clear and well-structured set of teaching practices in mind depending on the objectives to be achieved, might lead to negative effects on students' progress and active learning.

Based on the researchers' experience in issues related to methods of instruction, it can be noticed that some of the teaching practices implemented by instructors of English during the teaching process for preparatory year students at Taif University lack a number of teaching competencies required for effective teaching, which may limit students' active learning. These teaching practices may include vital competencies such as preparation, building background, classroom management, implementing effective teaching-learning strategies, classroom interaction, knowledge application, and assessment.

Relevant research may have reported various teaching competencies that might be similar in one way or another to the teaching competencies investigated in this paper. However, the context here is different since this paper aims to investigate the degree of instructors' implementation of the teaching competencies in the Preparatory Year Program at Taif University. In addition, It is important to point out that this academic year 1434/2013 is the second year of implementing this Program at university. So, being a relatively new program requires recruiting more staff to teach thousands of students enrolled in this program. Accordingly, the researchers believe that it will be valuable to investigate the teaching competencies implemented by instructors of English since these competencies have a direct impact on students' learning, which will be affected either positively or negatively. In 
other words, if the teaching practices are based on grounded competencies according to a professional development plan for instructors, this will have a positive impact on students' learning and achievement. In contrast, if teaching practices lack the necessary teaching competencies, this will have a negative effect on students' learning.

Lapp and Flood (1994) pointed out that teachers can use a number of strategies to make a learning material more approachable to learners such providing an encouraging environment for learners to express themselves and involving them in learning. Another important strategy is to develop learners' background knowledge.

To give more importance to the teaching competencies that provide teachers with the necessary knowledge and skills to cope with today's needs, Khasnavis and Morris (2001) pointed out that schools need education programs based on competencies in order to prepare teachers for the teaching profession. They stress the point that that teachers lack the teaching competencies necessary to meet today's and future needs.

The methods used by teachers tend to not make it easy for students to learn (Tharp, Esrada, Dalton, \& Yamauchi, 2000; Echevarria et al., 2006). Researchers pointed out that using oral instructional methods through lectures, for instance, makes it difficult for learners to understand information. In addition, paper and pencil activities that do not take scaffolded instruction into consideration might be challenging for learners (Rueda, 2001; Fillmore \& Snow, 2002; Echevarria et al., 2006).

Some researchers pointed out that certain teaching techniques include slower speech, use of visuals, scaffolded instruction, relating learning to learners' experiences, learner-to-learner interaction, adapting learning materials to students' level, and use of enrichment learning materials to support and enhance students' learning (Addison, 1988; Echevarria, 1995; Kauffman, Sheppard, Burkart, Peyton, \& Short, 1995; Genesee, 1999; Vogt, 2000; Echevarria \& Graves, 2003).

Jay and O'Conner (2005) pointed out that teachers in all subjects can use assessment to enhance learning and teaching. Classroom assessment aims to measure students' learning and promote it as well. They refer to summative assessment that summarizes what students have learned after an assigned learning outcome. Diagnostic and formative assessments provide certain feedback to teachers and students in order to guide their teaching to improve students' learning.

Polk (2006) identified ten basic characteristics of effective teachers. These include knowledge of pedagogical content, communication skills, prior performance, creativity, professionalism, student assessment, self-development, personality, content knowledge, and the ability to model concepts in their content area.

Henninger and Hurlbert (2006) emphasized the point that good teaching practice promotes student-teacher contact, cooperation among students themselves, and active learning. Besides, it gives immediate feedback and stresses the idea of time on task. He maintained that good teaching practice communicates high expectations and respects capabilities of talented students and styles of students' learning.

Weinstein (2008) was interested in showing how teachers perform in class. This includes how teachers and students communicate, learning styles, and how teachers can utilize their professional relations with other teachers.

\subsection{Problem Statement and Objective}

As EFL specialists having a direct contact with teaching and learning in the classroom, it has been noticed that EFL instructors' practices at Taif University lack a number of effective teaching competencies required for active and effective learning. These practices include aspects related to preparation for teaching, implementation of instruction, assessment and setting a suitable educational climate for learning. This research paper aims to examine the teaching competencies implemented by EFL instructors while teaching preparatory year students in order to identify which competencies enhance students' learning and those competencies that are rarely or not used, which may hinder students' learning.

\subsection{Research Questions}

The present research paper is an attempt to answer the following questions:

1) Which teaching competencies were used by Taif University instructors to enhance EFL students' learning in the Preparatory Year Program?

2) Which teaching competencies were rarely or not demonstrated by Taif University instructors while teaching EFL students in the Preparatory Year Program?

3) Are there any statistically significant differences in implementing the teaching competencies due to instructors' 
qualifications?

4) Are there any statistically significant differences in implementing the teaching competencies due to instructors' years of experience?

\subsection{Significance of the Study}

The results of this paper can be important to:

- Policy makers at university to follow up all the categories of the teaching competencies in their policies of instructors' professional development plans.

- EFL instructors to revisit their teaching practices that ranked low throughout their teaching plans.

- EFL instructors to share their expertise of the teaching practices that enhance students' active learning and involvement.

- Quality and Development Unit in the English Language Center to design and develop professional development sessions for instructors to develop their competencies in the areas that ranked low.

\subsection{Definition of Terms}

The following terms will have the associated meanings throughout the research paper:

- Teaching competencies: teaching practices implemented by EFL instructors while teaching English to students in the preparatory year. These include preparation, implementation of instruction, assessment and educational climate for learning.

- Preparatory Year Program: An academic program that lasts one year where high school graduates study fundamental and general subjects that prepare them to specialize in the next year.

\subsection{Limitations of the Research Paper}

The points below limit the generalization of the results of the present research paper:

- The present paper was limited to the four domains of the teaching competencies, namely preparation, implementation of instruction, assessment and educational climate for learning.

- The present paper was limited to male instructors' teaching English to EFL students in the preparatory year in the academic year 2013-2014.

\subsection{Review of Related Studies}

Burstein and Cabello (1989) pointed out that teacher training programs should provide teachers with knowledge and skills to work with students of different cultural backgrounds. They described a teacher education program designed to prepare teachers to work with those students. The program assumed that teachers must be able to make complicated decisions based on their beliefs, knowledge, and understanding of cultural diversity. The program focused on four levels of teacher development, namely knowledge, awareness, acquisition and maintenance of skills, and reflection. The researchers described the implementation of the model in one course, and discussed the effects of the program on teachers' beliefs, knowledge, and teaching practices with culturally diverse students.

Oliva and Henson (2001) identified twenty three essential teaching competencies to all teachers and grouped around five major categories: knowledge of basics, communication skills, technical skills, interpersonal skills and administrative skills.

Curtin (2005) conducted a qualitative research study to investigate the instructional methods used by teachers to deal with ESL students' needs. He used snow-balling and networking sampling technique to identify the participants of the study. He reached the conclusion that interaction as an instructional method that has a direct impact in terms of responding to students' needs. These teachers used more cooperative learning strategies than novice teachers who found it difficult to meet the individual learning needs of ESL students. The novice teachers focused mainly on subject content.

Tawalbeh (2005) carried out a study to investigate the effect of an in-service training program on developing EFL teachers' competencies in the Jordanian Lower Basic Stage. This program was developed by the researcher according to the EFL teachers' needs. The subjects of the study were 20 EFL teachers chosen from the target community which comprised 80 teachers. Two of the main questions raised in the study were: What are the teaching competencies needed by EFL teachers in Jordan? Which teacher competencies ranked higher due to the proposed in-service training program? The results indicated that teachers are in need of seven categories of competencies: methods of teaching, evaluation, co-curricular activities, classroom management, and problem 
solving, planning and error correction. However, the most needed competencies were: methods of teaching, classroom management, error correction techniques, and planning, respectively.

Whale (2006) stressed the importance of using technology in the classroom due to its positive impact on students' learning and achievement. He found that only one-fifth of teacher evaluations reviewed in 220 school districts include technology skills as a specific criterion with the majority of these occurring in larger districts. The researcher recommended that policy makers should improve the implementation of technology in schools.

Watzke (2007) conducted a longitudinal study to investigate how pedagogical content knowledge is represented during the beginning teaching experiences of nine teachers. The data consisted of reflective journal entries, classroom observations, and focus group interviews collected during the first two years of foreign language teaching in high school. The researcher identified four core categories to explain change in foreign language pedagogical content knowledge. The categories included prior knowledge, attitudes toward teacher control in the classroom, instructional goals, and considerations for responding to student affect. The results supported the proposition that communicative language developed pedagogical content knowledge through a process of teaching, conflict, reflection, and resolution.

To conclude, the teaching practices reported above include a number of competencies reported by previous studies. However, the context in this research paper is different. The present paper aims to investigate the teaching competencies that university instructors use while teaching students in their first year of learning English. So, investigating these teaching competencies will reveal which practices enhance students' learning so that instructors build on them and report them as best teaching practices. In addition, those teaching practices that may be rarely or not used effectively will be regarded as challenges facing instructors, and lead to negative effects on students' active learning. Accordingly, recommendations will be presented so that professional development programs will be designed and implemented.

\section{Method}

This part of the research paper discusses the methodology used to gather and analyze research data. It explains how population and sample of the study were identified, validity and reliability of the study instrument, procedures, and the statistical method followed to analyze data.

\subsection{Population and Sample Selection}

The population of the study consisted of all male Taif University instructors teaching English for preparatory year students. The total number was 70 . A convenient sampling technique was used to recruit the study participants. A sample of 33 male instructors was selected, which is about $50 \%$ of the population.

\subsection{Study Instrument}

The researchers developed a questionnaire of 46 items. It has been adapted from two projects from Echevarria, Vogt, \& Sort, 2000, 2004, and the Community College of Aurora's Mentor Program Handbook and Staffordshire University's Guidelines for the Observation of Teaching (Appendix A). Likert scale of four degrees $(1=$ not demonstrated, 2 = needs improvement, 3 = satisfactory, 4 = outstanding) was used to investigate the degree of implementing the teaching competencies by instructors. Numbers 1 and 2 indicate that there are difficulties hindering students' learning. And numbers 3 and four show that these items enhance students' learning. This means that a mean of 2 or less indicates a challenge in the teaching competency under investigation. The items have been formed positively so that each item stands for a positive statement.

\subsection{Instrument Validity and reliability}

The researchers believe that the observation checklist is valid since the items have been derived from two projects developed by a group of experts. However, it has been validated by asking a group of 7 EFL specialists to examine if the items were clear and relevant to the domains. They suggested that certain items should be omitted since they have been derived from two similar projects. In order to guarantee the reliability, the checklist was used to observe a sample of 10 instructors other than the participants of the study. The results were analyzed and the correlation coefficient (Pearson) between the previous and post observation was 0.88 . The Cronbach alpha reliability for the checklist was .89 .

\subsection{Study Procedures}

The researchers asked for official consent from the university Preparatory Year Deanship to observe the instructors in their classrooms for research purposes. Then, they identified the participants of the study and got their agreement to be observed. They also carried out the process of checklist validity and reliability. After that, the main researcher started the process of observation. In order to maintain quality results, the researcher 
selected three instructors who displayed good teaching practices and revisited them to see whether or not they keep on showing the same level of performance. The same was done for three instructors who displayed poor teaching competencies. Finally, the researchers processed the results to come up with the findings. Based on the findings, the researchers reached relevant conclusions and recommendations.

\subsection{Statistical Analysis}

The researcher used descriptive statistics to answer the first and the second questions related to the competencies implemented by instructors. To answer the third and fourth questions, one way ANOVA was used to examine whether or not there were any significant differences at $(\alpha=0.05)$ in implementing the teaching competencies due to instructors' qualifications and years of experience.

\section{Results}

To answer the first two questions about the competencies implemented by Taif University instructors, the table below shows the averages of the instructors' practices in the four domains included in the observation checklist.

Table 1. Averages of the instructors' practices in the four domains

\begin{tabular}{ll}
\hline Domain & Average \\
\hline The first domain: Preparation & 2.00 \\
The Second Domain: Instruction & 1.92 \\
The Third Domain: Review/ Assessment & 1.62 \\
The Forth Domain: Educational climate for learning & 2.19 \\
\hline
\end{tabular}

The table above shows that the first and the forth categories represent those items implemented by instructors to enhance EFL students' learning in the Preparatory Year Program. It is also evident that the second and third domains include competencies that were rarely or not demonstrated by instructors.

In order to highlight the teaching competencies where the instructors showed satisfactory performance, and those competencies that were rarely or not demonstrated, the tables below give more details of the averages of the instructors' practices in the items included under each domain of the observation checklist.

Table 2. Averages of the instructors' practices in the items of the first domain (preparation)

\begin{tabular}{|c|c|c|}
\hline No. & Item & Average \\
\hline & The instructor: & \\
\hline 1 & Defines objectives/outcomes for students verbally, written, or not at all & 2.57 \\
\hline 2 & Discusses objectives/outcomes at the end of class & 1.00 \\
\hline 3 & Provides examples that show preparation by instructor & 2.72 \\
\hline 4 & Makes content concepts suitable for students' age and educational background & 2.84 \\
\hline 5 & Uses supplementary materials to make the ideas clear and meaningful (graphs, visual aids) & 1.36 \\
\hline 6 & Adapts the lesson content to students' levels of proficiency & 2.48 \\
\hline 7 & $\begin{array}{l}\text { Demonstrates knowledge of teaching strategies and selects those that meet students' needs and } \\
\text { learning styles }\end{array}$ & 1.75 \\
\hline 8 & Designs interactive learning environment that ensures safety, students' cooperative learning & 1.30 \\
\hline
\end{tabular}

It is clear from the table above that the instructors demonstrated satisfactory teaching practices in items $1,3,4$ and 6. However, their practices in the other items were either rarely or not demonstrated. 
Table 3. Averages of the instructors' practices in the items of the second domain (instruction)

\begin{tabular}{|c|c|c|}
\hline No. & Item & Average \\
\hline & The instructor: & \\
\hline 9 & $\begin{array}{l}\text { (Building Background) links content concepts explicitly to students' background } \\
\text { knowledge }\end{array}$ & 2.72 \\
\hline 10 & $\begin{array}{l}\text { Emphasizes key vocabulary (introduced, written, repeated and highlighted for students } \\
\text { to see) }\end{array}$ & 2.42 \\
\hline 11 & $\begin{array}{l}\text { (Comprehensible input) makes his speech appropriate for the level of students' } \\
\text { proficiency }\end{array}$ & 2.72 \\
\hline 12 & Explains academic activities clearly & 2.60 \\
\hline 13 & $\begin{array}{l}\text { Uses a variety of techniques to make content concepts clear (e.g., modeling, visuals, } \\
\text { gestures, body language) }\end{array}$ & 1.36 \\
\hline 14 & $\begin{array}{l}\text { (Strategies and instructional methods) uses scaffolding instruction throughout the lesson, } \\
\text { helping and supporting students }\end{array}$ & 1.33 \\
\hline 15 & $\begin{array}{l}\text { Uses a variety of question types during the lesson (e.g., literal, analytical, and } \\
\text { interpretive questions) }\end{array}$ & 1.51 \\
\hline 16 & Makes the introduction gain the students' attention & 2.36 \\
\hline 17 & Maintains rapport & 2.60 \\
\hline 18 & $\begin{array}{l}\text { Introduces the topic, announces outcomes, presents material effectively, summarizes, and } \\
\text { gives assignment }\end{array}$ & 1.45 \\
\hline 19 & Emphasizes the most important points & 2.75 \\
\hline 20 & Gives examples to explain content clearly & 2.72 \\
\hline 21 & Presents a stimulating lecture & 2.33 \\
\hline 22 & $\begin{array}{l}\text { (Interaction) creates opportunities for interaction among students and between teacher } \\
\text { and students }\end{array}$ & 1.33 \\
\hline 23 & Asks students to work in pairs & 1.72 \\
\hline 24 & Asks students to work in groups & 1.12 \\
\hline 25 & Provides enough time for students' before output & 2.45 \\
\hline 26 & Urges students to summarize and add to partners' summaries & 1.12 \\
\hline 27 & Helps quiet students to interact with partners & 1.15 \\
\hline 28 & Communicates effectively with students to make their English learning easy & 1.48 \\
\hline 29 & (Practice/Application) provides students with hand-on materials to practice language & 1.00 \\
\hline 30 & Provides students with activities to apply knowledge in the classroom & 2.45 \\
\hline 31 & Utilizes activities that integrate more than one language skill & 1.39 \\
\hline 32 & Offers students opportunities to relate learning to real life & 2.00 \\
\hline
\end{tabular}

The table above shows that the instructors demonstrated satisfactory performance in half of the teaching competencies implemented in the classroom. These are $(9,10,11,12,16,17,19,20,21,25,30,32)$. In the other half of the items, the instructors' practices were either rarely or not demonstrated. 
Table 4. Averages of the instructors' practices in the items of the third domain (review/assessment)

\begin{tabular}{|c|c|c|}
\hline No. & Item & Average \\
\hline & The instructor: & \\
\hline 33 & Provides comprehensive review of most important vocabulary items & 2.75 \\
\hline 34 & Provides comprehensive review of most important content concepts & 2.75 \\
\hline 35 & Regularly provides feedback to students on their performance & 1.87 \\
\hline 36 & Uses varied assessment tools for students' English learning and progress & 1.00 \\
\hline 37 & $\begin{array}{l}\text { Keeps accurate records of students' learning and progress according to the intended } \\
\text { learning outcomes }\end{array}$ & 1.00 \\
\hline 38 & Provides opportunities of self-assessment and progress in English & 1.00 \\
\hline 39 & $\begin{array}{l}\text { Analyzes students' performance and provides them with feedback on their learning } \\
\text { and progress }\end{array}$ & 1.00 \\
\hline 40 & $\begin{array}{l}\text { Develops and implements appropriate activities to promote students' learning } \\
\text { according to the assessment results }\end{array}$ & 1.00 \\
\hline
\end{tabular}

The table above shows that the instructors demonstrated satisfactory performance in only items 33 and 34 . The rest were either rarely or not demonstrated.

Table 5. Averages of the instructors' practices in the items of the forth domain (educational environment)

\begin{tabular}{lll}
\hline No. & Item & Average \\
\hline & The instructor: & \\
41 & $\begin{array}{l}\text { Shows that he is interested and enthusiastic in students' performance and } \\
\text { participation }\end{array}$ & 2.27 \\
42 & Calls students' by their names & 2.93 \\
43 & Uses humor appropriately & 2.57 \\
44 & Makes sure that atmosphere promotes participation & 1.72 \\
45 & Uses eye contact & 3.00 \\
46 & Deals with students misbehavior effectively & 2.90 \\
\hline
\end{tabular}

The table above shows that the instructors demonstrated satisfactory performance in all the teaching practices except item number 44 .

As for the third question which seeks to answer if there are any statistically significant differences at $(\alpha \leq 0.05)$ in implementing the teaching competencies due to instructors' qualifications, the tables below show the means and standard deviation, and ANOVA test of the instructors' qualifications.

Table 6. Means and standard deviation of instructors' qualifications

\begin{tabular}{llll}
\hline Qualification Category & No. & Mean & Std. Deviation \\
\hline Bacheolor & 3 & 1.71 & .20 \\
Bacheolor and Diploma & 9 & 2.25 & .27 \\
Master & 21 & 1.83 & .22 \\
\hline Total & 33 & 1.93 & .30
\end{tabular}


Table 7. ANOVA test

\begin{tabular}{llllll}
\hline Groups & Sum of Squares & Df & Mean Square & F & Sig \\
\hline Between Groups & 1.299 & 2 & .649 & 11.110 & .000 \\
Within Groups & 1.753 & 30 & .058 & & \\
\hline Total & 3.052 & 32 & & & \\
\hline
\end{tabular}

The two tables above show that there are significant differences in implementing the teaching competencies due to instructors' qualifications.

In order to identify which qualification category made this difference, Post Hoc Scheffe test was made as shown in the table below.

Table 8. Post Hoc test/multiple comparisons (Scheffe)

\begin{tabular}{llcrr}
\hline Qualification & & Mean Difference & Std. Eror & Sig. \\
\hline Bacheolor & Bacheolor + Diploma & -.53935 & & .009 \\
Bacheolor + Diploma & Master & -.11409 & .16117 & .749 \\
& Master & 42526 & .14921 & .001 \\
\hline
\end{tabular}

It is evident from the table above that there are significant differences in implementing the teaching competencies for the sake of the instructors holding diploma after the bachelor degree.

To answer the forth question which aims to examine if there are any statistically significant differences at ( $\alpha \leq$ 0.05) in implementing the teaching competencies due to instructors' years of experience, the tables below show means and standard deviation, and ANOVA test of the instructors' years of experiences.

Table 9. Means and standard deviation of the instructors' years of experience

\begin{tabular}{llll}
\hline Years of Experience & No. & Mean & Std. Deviation \\
\hline less than 5 & 4 & 1.97 & .23347 \\
5 to 10 & 12 & 1.83 & .33073 \\
11 and more & 17 & 2.00 & .30569 \\
\hline Total & 33 & 1.93 & .30883 \\
\hline
\end{tabular}

Table 10. ANOVA test

\begin{tabular}{llllll}
\hline Groups & Sum of Squares & Df & Mean Square & F & Sig. \\
\hline Between Groups & .190 & 2 & .095 & .996 & .381 \\
Within Groups & 2.862 & 30 & .095 & & \\
\hline Total & 3.052 & 32 & & & \\
\hline
\end{tabular}

The tables above display that there are no statistically significant differences in implementing the teaching competencies in the Preparatory Year Program due to instructors' years of experience.

\section{Discussion and Conclusions}

As for the first two questions related to the teaching competencies implemented by Taif University instructors to enhance EFL students' learning in the Preparatory Year Program, and those competencies rarely or not demonstrated, it is clear that the first and the forth domains related to preparation for teaching and setting the educational climate for learning represent the teaching competencies used by instructors to enhance students' learning. The instructors displayed satisfactory performance in these two teaching competencies. This could be due to points related to instructors having expertise in these two competencies developed during their years of 
experience to an extent that enabled them to show satisfactory performance. It can also be claimed that competencies of preparation and setting the educational climate for learning are basic fundamentals needed for the teaching learning process. On the other hand, the second and the third competencies related to instruction and assessment were rarely or not demonstrated by instructors while teaching. It is possible that instructors have not undergone thorough professional development in issues related to the domain instruction such as strategies and instructional methods requiring instructors to use a variety of instructional methods and techniques, question types, frequent opportunities for interaction, summarization, discussion, practice and application. This is applicable to assessment as well where instructors displayed poor performance in assessing students' learning through varied assessment strategies and tools. Again, instructors may not have joined enough professional development sessions in assessing learning. It can be claimed that instruction and assessment are two competencies that require instructors to be well qualified in using a variety of strategies and instructional methods and assessment strategies and tools to enhance students' learning.

Regarding the third question which showed that there were statistically significant differences in implementing the teaching competencies due to instructors' qualifications in favor of instructors holding the diploma after the bachelor degree, this can be explained on the ground that this category of nine instructors out thirty three, having a diploma of EFL teaching methods made this difference. Those instructors have participated in CELTA (Certificate in English Language Teaching to Adults). This experience may have helped them gain the competencies that enabled them enhance students' learning to a satisfactory level in two of the competencies under investigation.

To discuss the forth question which indicated that there were no statistically significant differences in implementing the teaching competencies due to instructors' years of experience, it can be claimed that the educational context may not have supported years of experience to play a significant role in enhancing students' learning. This might be due to assigning one set of a learning material of a specified template to be followed in teaching English within a specified time limit, which entails traditional instructional methodology followed by instructors regardless of their years of experience in teaching English as a foreign language.

In conclusion, the previous studies reported are similar to this study in that they all handled one or more of the teaching competencies used by teachers to make an effect on students' learning. For example, one study discussed competencies related to encouraging environment and deep personal involvement (Lapp \& Flood, 1994). Other studies discussed oral instruction through lectures and scaffolded instruction (Addisson, 1988; Rueda, 2001; Fillmore \& Snow, 2002; Echevarria et al., 2006). Others handled interaction and use of supplementary materials (Echevarria, 1995; Vogt, 200). Another study on assessment was carried out by Jay, and O'Conner (2005) and Polk (2006). One more study studied the effect of practice on learning was carried out by Henninger and Edward (2006).

Some of the teaching competencies highlighted above were included in the present study. However, this research paper aimed to examine a more comprehensive set of teaching competencies implemented by instructors while teaching English to preparatory year students at Taif University. It tried to investigate competencies related to preparation for teaching, implementation of instruction, review and assessment, and setting the educational climate for learning.

\section{Recommendations}

Based on the results of the research paper, the researchers recommended the following:

1) Policy makers should follow up the teaching competencies that were rarely or not demonstrated as these competencies play a significant role in maximizing students' opportunities of learning English in the Preparatory Year Program at Taif University.

2) Continuous professional development meetings for instructors to handle the domains of teaching competencies that were rarely or not used by instructors. Sessions may include issues related to implementation of instruction and assessment of students' learning.

3) Other papers should be carried out to investigate the teaching practices implemented by female EFL instructors at Taif University to see if there are any differences between male and female instructors while teaching English for preparatory year students.

\section{Acknowledgements}

The researcher would like to acknowledge the contribution of the instructors who validated the study instrument and those who were observed in their classes. Many thanks go to the co-author who assisted in conducting the study. Special thanks also go to the colleagues who assisted in the manuscript preparation. 


\section{References}

Addison, A. (1988). Secondary Focus on Sheltered Content Instruction: Adapting Core Curriculum Materials for LEP Students. California Association for Bilingual Education Newsletter, 13.

Burstein, N. D., \& Cabello, B. (1989). Preparing Teachers to Work with Culturally Diverse Students: A Teacher Education Model. Journal of Teacher Education, 40(5), 9-16. http://dx.doi.org/10.1177/002248718904000502

Curtin, E. (2005). Instructional Styles used by Classroom Teachers while Teaching mainstreamed ESL Students: Six Urban Middle School Teachers in Texas Share their Experiences and Perceptions. Multicultural Education, 12(4), 36-42.

Echevarria, J. (1995). Sheltered instruction for students with learning disabilities who have limited English proficiency. Intervention in School and Clinic, 302-305. http://dx.doi.org/10.1177/105345129503000509

Echevarria, J., \& Graves, A. (2003). Sheltered content instruction: Teaching English language learners with diverse abilities. Boston: Allyn \& Bacon.

Echevarria, J., Short, D., \& Powers, K. (2006). School Reform and Standards-Based Education: A model for English Language Learners. The Journal of Educational Research, 99(4), 195-210. http://dx.doi.org/10.3200/JOER.99.4.195-211

Fillmore, L. W., \& Snow, C. (2002). What Teachers Need to Know about Language. In C. T. Adger, C. E. Snow, \& D. Christian (Eds.), what teachers need to know about language? (pp. 7-53). McHenry, IL: Delta Systems and Center for Applied Linguistics.

Genesee, F. (Ed.). (1999). Program alternatives for linguistically and culturally diverse students (Educational Practice Report No. 1). Santa Cruz, CA: Center for Research on Education, Diversity \& Excellence.

Henninger, E. A., \& Huribert, J. M. (2006). Using the Seven Principles for Good Practice in Undergraduate Education. Journal of Business and Finance Librarianship, 12(2), 3-15. http://dx.doi.org/10.1300/J109v12n02_02

Jay, M., \& O’Conner, K. (2005). Seven Practices for Effective Learning. Educational Leadership, 63(3), 10-17.

Kauffman, D., Sheppard, K., Burkart, G., Peyton, J., \& Short, D. (1995). Content-ESL across the USA (Vol. II, Tech. Rep.). Washington, DC: National Clearinghouse for Bilingual Education.

Khasnavis, P. K., \& Morris, J. P. (2001). A Competency-Based Teacher Education Program for the Future. Education, 98(2), 185-187.

Lapp, D., \& Flood, J. (1994). Are We Communicating? Effective Instruction for Students Who are Aquiring English as a Second Language. The Reading Teacher, 48(3), 260-264.

Oliva, P. F., \& Henson, K. T. (2001). What are the Essential Generic Teaching Competencies? Education, 19(2), 117-121.

Plok, J. A. (2006). Traits of Effective Teachers. Arts Educational Policy Review, 107(4), 23-29. http://dx.doi.org/10.3200/AEPR.107.4.23-29

Rueda, R., \& Garcia, G. (2001). How do I teach Reading to ELLs? Ninth in a series: Teaching Every Child to Read. Ann Arbor, MI: Center for the Improvement of Early Reading Achievement.

Tawalbeh, T., (2005). The Effect of an In-Service Training Program on Developing EFL Teaching Competencies in the Lower Basic Stage in Jordan (Unpublished PhD dissertation). Amman Arab University for Graduate Studies.

Tharp, R., Estrada, P., Dalton, S., \& Yamauchi, L. (2000). Teaching transformed: Achieving excellence, fairness, inclusion and harmony. Boulder, CO: Westview Press.

Vogt, M. E. (2000). Content learning for students needing modifications: An issue of access. In M. McLaughlin, \& M. E. Vogt (Eds.), Creativity and innovation in content area teaching (pp. 329-351). Norwood, MA: Christopher-Gordon.

Watzke, J. L. (2007). Foreign Language Pedagogical Knowledge: Toward a Developmental Theory of beginning Teacher Practices. Modern Language Journal, http://dx.doi.org/10.1111/j.1540-4781.2007.00510.x 
Weinstein, N. (2008). Teacher Competency Evaluation. EBSCO Research Starters.

Whale, D. (2006). Technology Skills as a Criterion in Teacher Evaluation. Journal of Technology and Teacher Education, 14(1), 61-74.

\section{Appendix}

The observation Checklist

Part 1:

\begin{tabular}{|c|c|c|c|c|c|c|c|c|c|}
\hline Qualification & B.A & ( & ) & B.A +Diploma & ( & ) & $\mathrm{MA}$ & ( & ) \\
\hline Years of experience & Less than 5 & ( & ) & $5-10$ & ( & ) & 11 and more & ( & ) \\
\hline
\end{tabular}

Part 2:

\begin{tabular}{|c|c|c|c|c|c|}
\hline \multicolumn{2}{|c|}{ Domains } & \multicolumn{4}{|l|}{ Degree } \\
\hline & $\begin{array}{l}\text { The First Domain: Preparation } \\
\text { The instructor: }\end{array}$ & $\begin{array}{l}\text { Not } \\
\text { demonstrated }\end{array}$ & $\begin{array}{l}\text { Needs } \\
\text { improvement }\end{array}$ & Satisfactory & Outstanding \\
\hline 1 & $\begin{array}{l}\text { Defines objectives/outcomes for students } \\
\text { verbally, written, or not at all }\end{array}$ & & & & \\
\hline 2 & $\begin{array}{l}\text { Discusses objectives/outcomes at the end } \\
\text { of class }\end{array}$ & & & & \\
\hline 3 & $\begin{array}{l}\text { Provides examples that show preparation } \\
\text { by instructor }\end{array}$ & & & & \\
\hline 4 & $\begin{array}{l}\text { Makes content concepts suitable for } \\
\text { students' age and educational background }\end{array}$ & & & & \\
\hline 5 & $\begin{array}{l}\text { Uses supplementary materials to make the } \\
\text { ideas clear and meaningful (graphs, visual } \\
\text { aids) }\end{array}$ & & & & \\
\hline 6 & $\begin{array}{l}\text { Adapts the lesson content to students' } \\
\text { levels of proficiency }\end{array}$ & & & & \\
\hline 7 & $\begin{array}{l}\text { Demonstrates knowledge of teaching } \\
\text { strategies and selects those that meet } \\
\text { students' needs and learning styles }\end{array}$ & & & & \\
\hline 8 & $\begin{array}{l}\text { Designs interactive learning environment } \\
\text { that ensures safety, students' cooperative } \\
\text { learning }\end{array}$ & & & & \\
\hline & The second Domain: Instruction & & & & \\
\hline & The instructor: & & & & \\
\hline 9 & $\begin{array}{l}\text { (Building Background) links content } \\
\text { concepts explicitly to students' background } \\
\text { knowledge }\end{array}$ & & & & \\
\hline 10 & $\begin{array}{l}\text { Emphasizes key vocabulary (introduced, } \\
\text { written, repeated and highlighted for } \\
\text { students to see) }\end{array}$ & & & & \\
\hline 11 & $\begin{array}{l}\text { (Comprehensible input) makes his speech } \\
\text { appropriate for the level of students' } \\
\text { proficiency }\end{array}$ & & & & \\
\hline
\end{tabular}


12 Explains academic activities clearly

Uses a variety of techniques to make

13 content concepts clear (e.g., modeling, visuals, gestures, body language)

(Strategies and instructional methods) uses scaffolding instruction throughout the lesson, helping and supporting students

Uses a variety of question types during the

15 lesson (e.g., literal, analytical, and interpretive questions)

\begin{tabular}{llll}
\hline & $\begin{array}{l}\text { Not } \\
\text { demonstrated }\end{array}$ & $\begin{array}{l}\text { Needs } \\
\text { improvement }\end{array}$ & Satisfactory Outstanding \\
\hline
\end{tabular}

16 Makes the introduction gain the students' attention

17 Maintains rapport

Introduces the topic, announces outcomes,

18 presents material effectively, summarizes, and gives assignment

19 Emphasizes the most important points

20 Gives examples to explain content clearly

21 Presents a stimulating lecture (Interaction)

22 creates opportunities for interaction among students and between teacher and students

23 Asks students to work in pairs

24 Asks students to work in groups

25 Provides enough time for students' before output

26 Urges students to summarize and add to partners' summaries

27 Helps quiet students to interact with partners

28 Communicates effectively with students to make their English learning easy

29 (Practice/Application) provides students with hand-on materials to practice language

30 Provides students with activities to apply knowledge in the classroom

31 Utilizes activities that integrate more than one language skill

Offers students opportunities to relate learning to real life

The Third Domain: Review/Assessment

The instructor:

33 Provides comprehensive review of most 
important vocabulary items

34 Provides comprehensive review of most important content concepts

35 Regularly provides feedback to students on their performance

36 Uses varied assessment tools for students' English learning and progress

Keeps accurate records of students'

37 learning and progress according to the intended learning outcomes

38

Provides opportunities of self-assessment and progress in English

Analyzes students' performance and

39 provides them with feedback on their learning and progress

Develops and implements appropriate

40 activities to promote students' learning according to the assessment results

The Fourth Domain: Educational climate for learning

The instructor:

41 Shows that he is interested and enthusiastic in students' performance and participation

42 Calls students' by their names

43 Uses humor appropriately

44 Makes sure that atmosphere promotes participation

45 Uses eye contact

46 Deals with students misbehavior effectively

\section{Copyrights}

Copyright for this article is retained by the author(s), with first publication rights granted to the journal.

This is an open-access article distributed under the terms and conditions of the Creative Commons Attribution license (http://creativecommons.org/licenses/by/3.0/). 